\title{
Evaluation of Improved and Selected Brachiaria Grass Cultivars in DRC
}

\author{
Musale M. D. Katunga ${ }^{1,2,3}$, Mbusa Tshikoly ${ }^{1}$, Losimba M. Bofunga ${ }^{1}$, Dhengo Ngona ${ }^{1}$, \\ Katunga F. Balemirwe' ${ }^{3}$, Balemirwe Mushagalusa², Mukengere P. Nshokano², \\ Ntumulo P. Mugisho
}

\footnotetext{
${ }^{1}$ Programme National de Recherche Sur l'élevage (PNRE), Institut National Pour l'Etude et la Recherche Agronomiques (INERA), Nioka, Democratic Republic of the Congo

${ }^{2}$ Programme National de Recherche Sur l'élevage (PNRE), Institut National Pour l'Etude et la Recherche Agronomiques (INERA), Mulungu, Democratic Republic of the Congo

${ }^{3}$ Faculté de Médecine Vétérinaire, Université du Cinquantenaire de Lwiro, Bukavu, Democratic Republic of the Congo

Email: stylonya@gmail.com
}

How to cite this paper: Katunga, M.M.D. Tshikoly, M., Bofunga, L.M., Ngona, D., Balemirwe, K.F., Mushagalusa, B., Nshokano, M.P. and Mugisho, N.P. (2021) Evaluation of Improved and Selected Brachiaria Grass Cultivars in DRC. Open Access Library Journal, 8: e8042.

https://doi.org/10.4236/oalib.1108042

Received: October 2, 2021

Accepted: December 27, 2021

Published: December 30, 2021

Copyright $\odot 2021$ by author(s) and Open Access Library Inc.

This work is licensed under the Creative Commons Attribution International License (CC BY 4.0).

http://creativecommons.org/licenses/by/4.0/

\begin{abstract}
Food security has become a major concern in DRC. Animal production decreases dramatically due to wars while still managed in an extensive system. Productivity is low due especially to low diseases control, lack of animal feed and low extension services. Meanwhile, the DRC has a huge agricultural potential characterized by sufficient rainfall, a major river system, a high diversity of soils and broad sunshine. To contribute to face this malnutrion, three Brachiaria varieties: $B$. decumbens $\mathrm{CV}$. Basilisk, B. brizantha (CVs. Xaraes, Piatã) and two controls: Pennisetum purpureum and Brachiaria ruziziensis were evaluated in the multi-location trials in Nioka and Mulungu in Randomized Complete Block Design with 4 replications. Space between replication was $1 \mathrm{~m}$. Basal manure was applied at $8 \mathrm{t} / \mathrm{ha}$ in both sites. After land preparation, each hole received one plantlet of forages evaluated. Parameters observed every 4 weeks in the plot randomly placed over the 2 central rows during one year were: pests and diseases attacks; number of tillers; plant height. To assess the dry matter yield, cutting was randomly placed over the 2 central rows of the herbage every 8 weeks. Harvested fresh material was weighed and sub-sample ( $400 \mathrm{~g}$ ) collected and dried at $105^{\circ} \mathrm{C}$ for 48 hours for dry weight determination. Data were analyzed by Statistix 0.8 software. Results showed that pests and diseases attacks were not significantly important for all the forage species and cultivars. Brachiaria Cultivars' evaluation showed successively that the two best forages based on a number of tillers were $B$. decumbens CV. Basilisk 78.4 and B. ruziziensis 54.5, on the height there were $P$. purpureum $279.7 \mathrm{~cm}$ and $B$. brizantha CV. Piata, $100.9 \mathrm{~cm}$ and
\end{abstract}


on weight biomass $B$. decumbens $\mathrm{CV}$. Basilisk $3320.3 \mathrm{Kg} \mathrm{DM} \mathrm{ha}^{-1}$ and $P$. purpureum $3175.5 \mathrm{Kg} \mathrm{DM} \mathrm{ha}{ }^{-1}$. The two other Brachiaria Cultivars introduced can be also recommended to the farmers according to their good yield.

\section{Subject Areas}

Agricultural Science

\section{Keywords}

Forages, Brachiaria, Adaptation, Growth, Yield

\section{Introduction}

Located in Central Africa, the Democratic Republic of the Congo (DRC) has $2.345 .409 \mathrm{~km}^{2}$ of national territory, 71.712 .867 inhabitants with $65 \%$ in the rural area. Rate of population increasing is $3.5 \%$ per year. Contribution of agriculture to GDP is $43 \%$ in 2009 [1] and as proportion of livestock GDP 9.2\% [2]. Major livestock species and their numbers are: cattle 755,500, sheep 900,470, goats 4,027,950, swine 961,090 chickens and 19,080,437 [3].

Mulungu soils are from recent volcanic eruption with $\mathrm{pH}$ (water) 5.2, $\mathrm{K}$ (EXK100G) 0.4, Ca (EXK100G) 7.5 [4] when in Nioka, soils origin is from granite [5]. Food security has become a major concern for the entire population in DRC. This is particularly the case of animal proteins and crops which are not enough to nourish people. Animal production decreases considerably due to recent wars while it remains managed in an extensive system [4]. Productivity is low due especially to low diseases control, lack of animal feed and low extension services [6]. Meanwhile, the Democratic Republic of the Congo has a huge agricultural potential characterized by sufficient rainfall, a major river system, a high diversity of soils and broad sunshine [7]. Despite this importance, in South Kivu, consumption of red meat, pork and chicken was low in all Mandate Areas with an exception of Ruzizi plains where the average consumption frequency of red meat was 4 times a month [8].

To contribute to facing the problems of lack of animal proteins in DRC, Bec'A-ILRI decided in this work to reintroduce in Sud-Kivu and Ituri provinces, some cultivars of improved brachiaria from CIAT in South America.

\section{Materials and Methods}

Treatments: The Brachiaria in this evaluation included three varieties: $B$. decumbens CV. Basilisk, B. brizantha (CVs. Xaraes, Piatã) and two controls; Napier grass Pennisetum purpureum (P. purpureum) and Brachiaria ruziziensis ( $B$. ruziziensis) were evaluated in the multi-location trials in Nioka, Mahagi territory, Ituri province and at Mulungu in Kabare territory, Sud-Kivu province. Nioka is located in North Hemisphere while Mulungu is in South Hemisphere of DRC. 
Design: Randomized Complete Block Design with 4 replications.

Plot size: $4 \mathrm{~m} \times 5 \mathrm{~m}=20 \mathrm{~m}^{2}$ (10 rows per plot), the space between replication was $1 \mathrm{~m}$.

Basal fertilizer. Manure was applied at 8 ton/ha in both sites.

Land preparation: Plough and harrow the land twice to a fine tilth. All other grasses were eliminated by weeding using hand hoe.

\subsection{Forages Establishment Phase}

Sowing/ transplanting: was done with more than 4 seeds per hole. In Mulungu site, sowing was done in June, 2017, the seedling emergence was observed in August, 2017. In Nioka, sowing was done in December, 2018, seedling emergence observed in January, 2018. After the seedling's emergence was observed, all the holes were planted and only one plantlet per hole was kept in all the sites. Following parameters were observed every 4 weeks in the plot randomly placed over the 2 central rows during one year:

Pests and diseases. Assess pests and diseases incidences;

Number of tillers. Number of tillers was counted per plant from 4 plants within the $1 \times 1 \mathrm{~m}$;

Plant height: Height of 4 plants within the $1 \times 1 \mathrm{~m}$ frame.

\subsection{Forages Production Phase}

Dry matter yield: Cutting was randomly placed over the 2 central rows every 8 weeks the herbage from $1 \times 1 \mathrm{~m}^{2}$ net harvest area. Cutting regulation in Nioka was done in May 2019 and harvest times from November 2019 to September 2020. In Mulungu the cutting regulation was done in November 2019 and harvest times were from January 2020 to November 2020. In both two sites, cuttings were done every 8 weeks for one year. Harvested fresh material was weighed and sub-sample $(400-500 \mathrm{~g})$ collected and dried at $105^{\circ} \mathrm{C}$ for 48 hours for dry weight determination. Data were analyzed by Statistix 0.8 software.

\section{Results}

\subsection{Seedling Emergence}

The rates of seedlings emergence were generally good in Mulungu than in $\mathrm{Ni}$ oka. At all, $100 \%$ of holes were planted with one plantlet per hole (Table 1).

Table 1. Rates of seedling emergence.

\begin{tabular}{|c|c|c|c|c|c|c|c|c|c|c|}
\hline \multirow{2}{*}{ Species and Cultivars } & \multicolumn{5}{|c|}{ Repetitions/Nioka } & \multicolumn{5}{|c|}{ Repetitions/Mulungu } \\
\hline & $1^{\text {st }}$ rep. & $2^{\text {nd }}$ rep. & $3^{\text {rd }}$ rep. & $4^{\text {th }}$ rep. & Mean rate & $1^{\text {st }}$ rep. & $2^{\text {nd }}$ rep. & $3^{\text {rd }}$ rep. & $4^{\text {th }}$ rep. & Mean rate \\
\hline B. decumbens CV Basilisk & 69 & 52 & 72 & 72 & 66 & 100 & 100 & 100 & 100 & 100 \\
\hline B. brizantha CV Piata & 96 & 90 & 78 & 84 & 87 & 85 & 100 & 89 & 85 & 90 \\
\hline B. brizantha CV Xaraes & 75 & 96 & 95 & 95 & 90 & 100 & 100 & 82 & 100 & 96 \\
\hline P. purpureum & 97 & 97 & 91 & 98 & 96 & 100 & 100 & 100 & 100 & 100 \\
\hline B. ruziziensis & 75 & 46 & 74 & 80 & 69 & 100 & 100 & 100 & 100 & 100 \\
\hline
\end{tabular}




\subsection{Insects and Diseases Attacks}

The means of insect and diseases attacks were not important for all the forage species and Cultivars (Table 2).

\subsection{Number of Tillers}

The number of tillers was respectively in ascendant order B. decumbes CV. Basilisk (BdecBasili) 78.4, B. ruziziensis (Br) 54.5, B. brizantha CV. Xaraes (BbrizXarae) 38.4, B. brizantha CV. Piata (BbrizPiata) 38.2, and P. purpureum (Pp) 35.9 (Figure 1).

There was significant difference $(P<0.001)$ between the means of forage species and Brachiaria Cultivars tiller numbers.

According to the sites, Mulungu realized a mean of 60.4 tillers when Nioka had only 29.2 tillers (Figure 2$)$. There was significant difference $(\mathrm{P}<0.001)$ between the means of the number of tillers in the sites. Mulungu counted many tillers than Nioka.

Table 2. Insects and diseases.

\begin{tabular}{|c|c|c|c|c|c|c|c|c|}
\hline & \multicolumn{4}{|c|}{ Nioka } & \multicolumn{4}{|c|}{ Mulungu } \\
\hline & $\begin{array}{l}\text { Insect } \\
\text { inci }^{*} 1\end{array}$ & $\begin{array}{c}\text { Ext } \\
\text { insect } d^{*} 2\end{array}$ & $\begin{array}{c}\text { Dise } \\
\text { inci }^{*} 3\end{array}$ & $\begin{array}{c}\text { Ext } \\
\text { disease }^{\star} 4\end{array}$ & $\begin{array}{l}\text { Insect } \\
\text { inci }{ }^{*} 1\end{array}$ & $\begin{array}{c}\text { Ext } \\
\text { insect } d^{*} 2\end{array}$ & $\begin{array}{c}\text { Dise } \\
\text { inci }{ }^{*} 3\end{array}$ & $\begin{array}{c}\text { Ext } \\
\text { disease }^{\star} 4\end{array}$ \\
\hline B. decumbens CV Basilisk & 0 & 0 & 0 & 0 & 0 & 0 & 0 & 0 \\
\hline B. brizantha CV. Piata & 0 & 0 & 0 & 0 & 0 & 0 & 0 & 0 \\
\hline B. brizantha CV. Xaraes & 0 & 0 & 0 & 0 & 0 & 0 & 0 & 0 \\
\hline$P$. purpureum & 0 & 0 & 0 & 0 & 0 & 0 & 0 & 0 \\
\hline B. ruziziensis & 0 & 0 & 0 & 0 & 0 & 0 & 0 & 0 \\
\hline
\end{tabular}

Insect inci ${ }^{\star} 1=$ insect incidence, Ext insect $\mathrm{d}^{\star} 2=$ extent of insect damage, Dise inci ${ }^{\star} 3=$ disease incidence and Ext disease ${ }^{\star} 4=$ ex- $^{-}$ tent of disease.

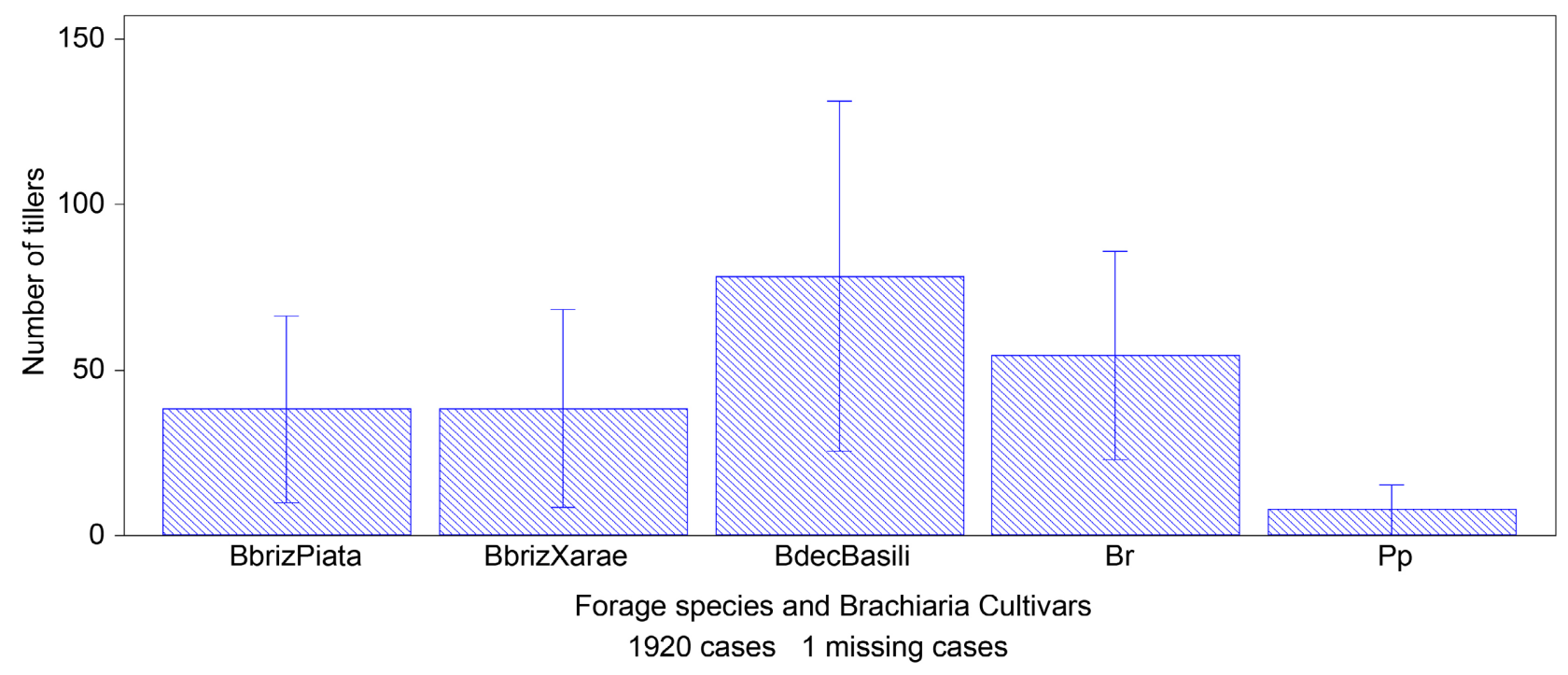

Figure 1. Forages species and brachiaria cultivars number of tillers. 


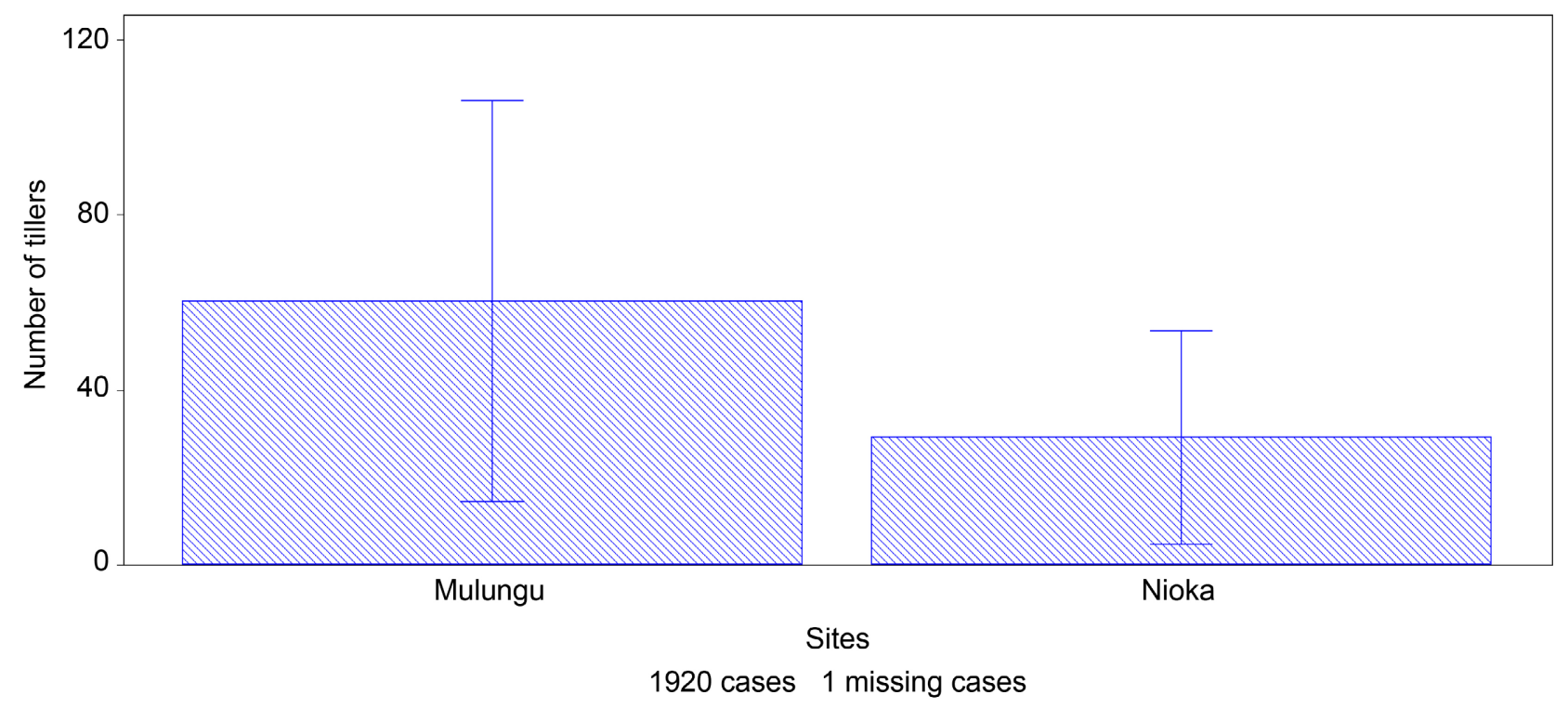

Figure 2. Number of tillers per site.

\subsection{Forages Height}

Heights presented in ascending order were for the tallest $P$. purpureum $279.7 \mathrm{~cm}$ followed by $B$. brizantha CV. Piata $100.9 \mathrm{~cm}, B$. decumbens Basilisk $96.7 \mathrm{~cm}, B$. brizantha CV. Xaraes $92.8 \mathrm{~cm}$ and B. ruziziensis $54.5 \mathrm{~cm}$ (Figure 3).

There was significant difference $(\mathrm{P}<0.001)$ between the height means of the forage species and Brachiaria Cultivars in Nioka than in Mulungu site, Pennisetum purpureum was the tallest.

There was no significant difference between the means heights $(P>0.05)$ by the Student's t-test of heights forage species and Cultivars between the two sites.

\subsection{Dry Matter Yield}

Means dry matter of the forage species and Brachiaria Cultivars were significantly different $\mathrm{P}<0.0001$ between the means of forages and Brachiaria Cultivars respectively in ascendant order for B. CV. decumbens Basilisk $3320.3 \mathrm{Kg}$ $\mathrm{DM} \mathrm{ha}^{-1}$, P. purpureum $3175.5 \mathrm{Kg} \mathrm{DM} \mathrm{ha}{ }^{-1}$, B. CV. brizantha Piata $2914.5 \mathrm{Kg}$ $\mathrm{DM} \mathrm{ha}^{-1}$, B. brizantha CV. Xaraes $2837.5 \mathrm{Kg} \mathrm{DM} \mathrm{ha}^{-1}$ and B. ruziziensis 1677.7 $\mathrm{Kg} \mathrm{DM} \mathrm{ha}{ }^{-1}$ (Figure 4). These results showed that the high weight of biomass was recorded by B. decumbens $\mathrm{CV}$. Basilisk followed by P. purpureum.

Compare to the sites, there was a highly significant difference $\mathrm{P}<0.0001$ between the means of dry matter yield of forages and Brachiaria Cultivars in the sites. Mulungu site recorded to produce more biomass $3064.8 \mathrm{Kg} \mathrm{DM} \mathrm{ha}^{-1}$ than Nioka with 2505.4 Kg DM ha-1 (Figure 5).

\section{Discussion}

\subsection{Insects and Diseases Attacks}

Pests and diseases attack don't have a negative influence on the development of 


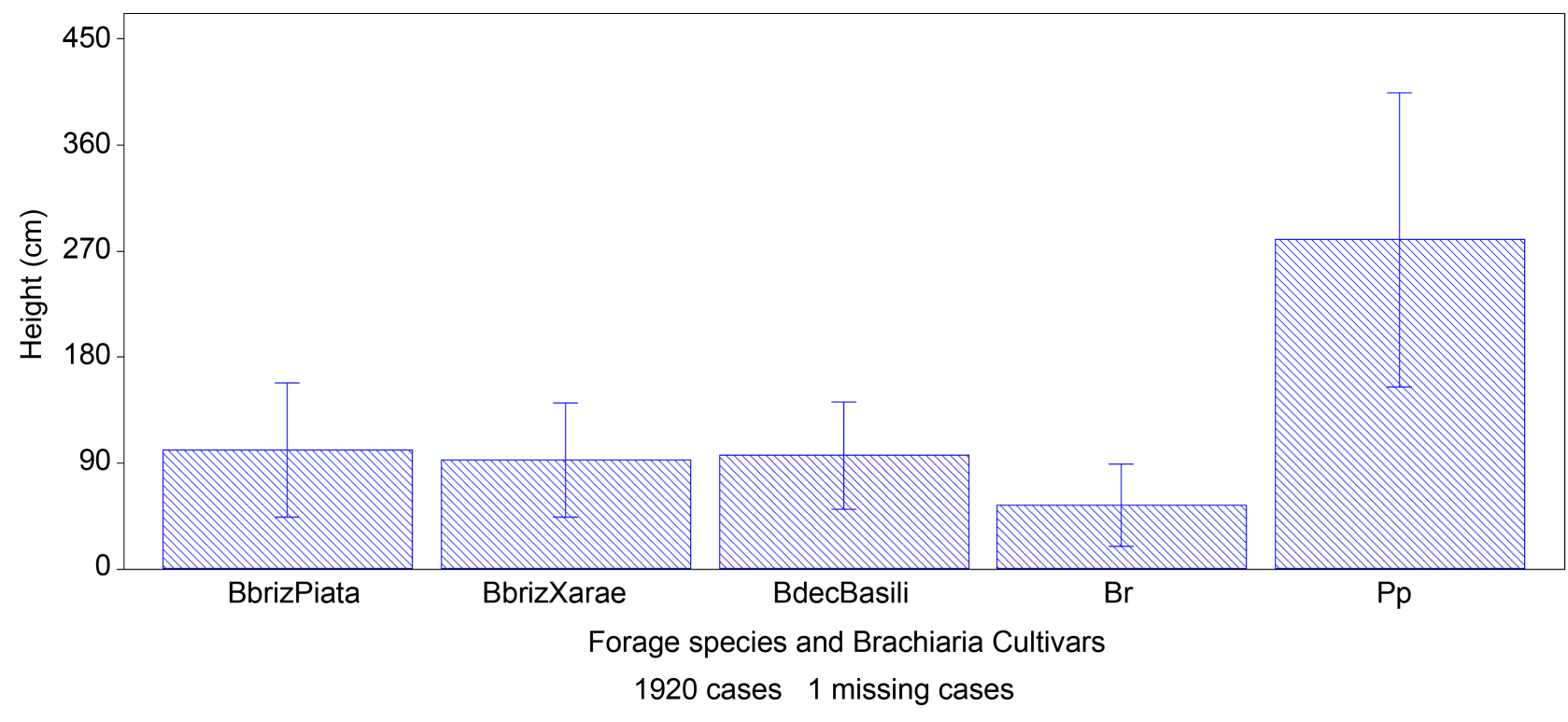

Figure 3. Forages height.

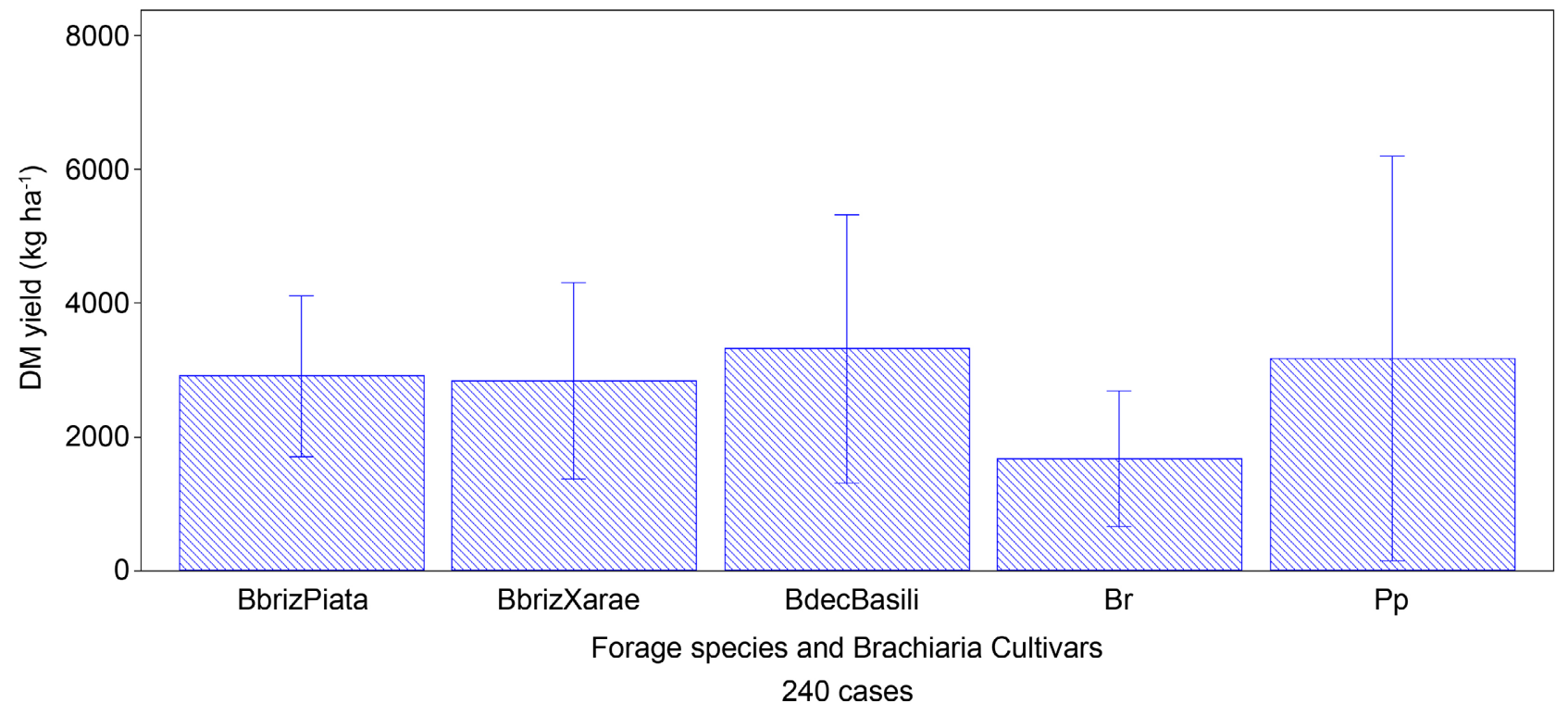

Figure 4. Forages dry matter yield.

the forages observed. However, according to the monthly observations some nematodes attacked especially the leaves of Brachiaria ruziziensis and in certain conditions B. decumbens CV. Basilisk, B. brizantha CV. Piata, B. brizanha CV. Xaraes. Only $P$. purpreum resisted to these attacks. [9] observed that red spider mites attacked the underside of the leaves while the grass midge and shoot fly attacked the young growing tillers.

\subsection{Number of Tillers}

B. decumbens CV. Basilisk had the big number of tillers, 78.4 followed by B. ruziziensis with 54.5. In Brazil, B. decumbens CV. Xaraes had 41.5, B. brizantha 


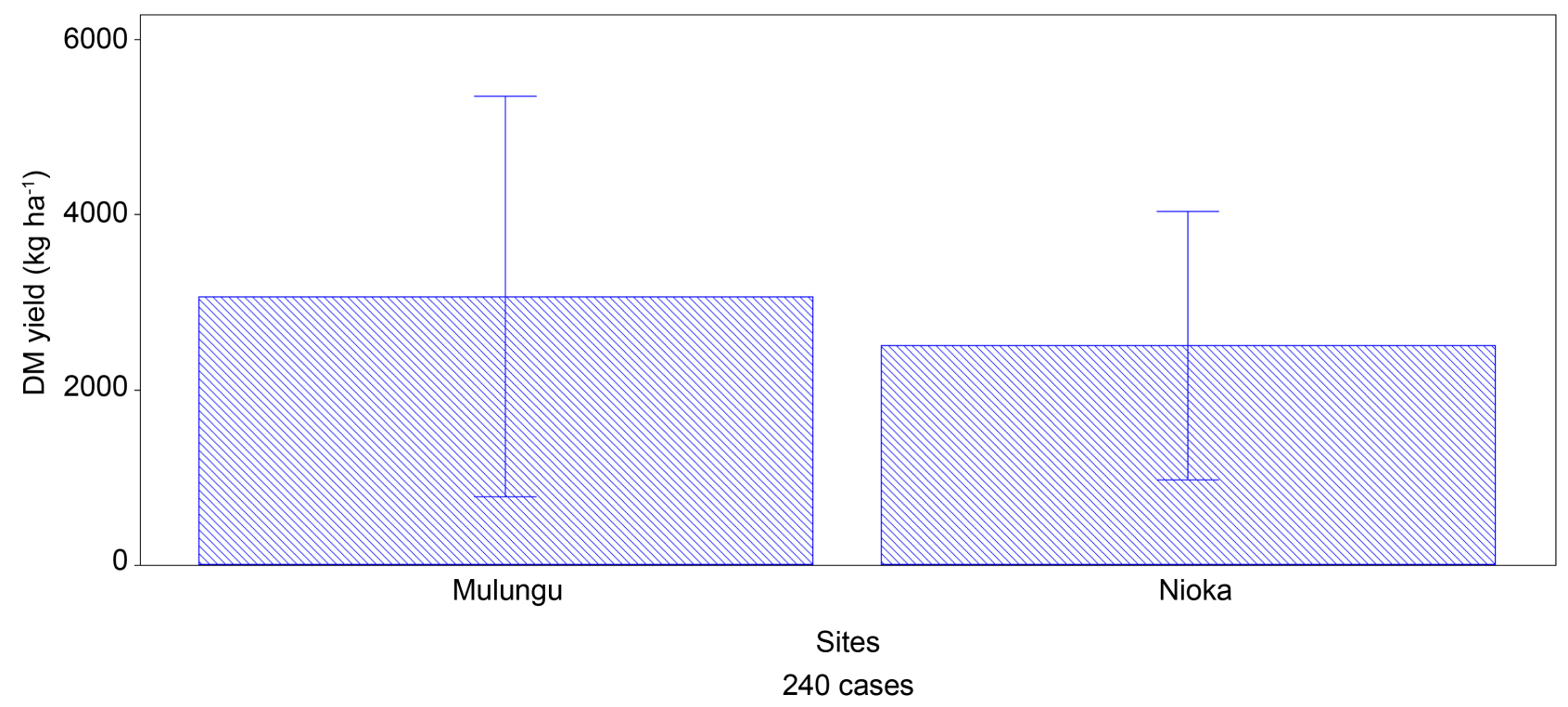

Figure 5. Forages dry matter per site.

CV. Piata 48.7 and B. ruziziensis had 46.5 [10]. The number of tillers compared to the sites, Mulungu had the big number than Nioka.

\subsection{Height}

The tallest forage was $P$. purpureum in both the two sites even if there were any differences of heights between the sites. At 8 weeks after emergence, [11] observed that $P$. purpureum $9.2 \mathrm{~cm}$ was tallest followed in ascendant order by $B$. brizantha CV. Xaraes $5.3 \mathrm{~cm}, B$. decumbens $\mathrm{CV}$. Basilisk $4 \mathrm{~cm}$ and $B$. brizantha CV. Piata $3.5 \mathrm{~cm}$.

\subsection{Dry Matter Yield}

B. decumbens $\mathrm{CV}$. Basilisk produced more dry matter yield in all the sites and was followed by one of the control $P$. purpureum. In Rwanda $P$. purpureum produced 17.2 t $\mathrm{DM} \mathrm{ha}^{-1}$ under legume intercropping and mulch on yield [12] which is so high than in DRC where we observed $3.2 \mathrm{t} \mathrm{DM} \mathrm{ha}^{-1}$. [10] observed that the dry matter yield after mineral fertilizer application on $B$. decumbens CV. Xaraes was $11,636 \mathrm{~kg} \mathrm{DM} \mathrm{ha}^{-1}, B$. brizantha CV. Piata $6708 \mathrm{~kg} \mathrm{DM} \mathrm{ha}^{-1}, B$. ruziziensis $8940 \mathrm{~kg} \mathrm{DM} \mathrm{ha}{ }^{-1}$. Various dry matters yields were observed in Msabaha (Kenya) on B. decumbens CV. Basilisk $3700 \mathrm{~kg} \mathrm{DM} \mathrm{ha}^{-1}$, Brazil, B. decumbens CV. Xaraes $2000 \mathrm{~kg} \mathrm{DM} \mathrm{ha}^{-1}$, B. brizantha CV. Piata $2600 \mathrm{~kg} \mathrm{DM} \mathrm{ha}^{-1}$, they were rather less than those implemented in DRC [13].

\section{Conclusions}

Results of Brachiaria Cultivars evaluation in DRC showed that based on number of tillers $B$. decumbens CV. Basilisk was the first. According to the height, the three cultivars introduced followed $P$. purpureum. The high weight of biomass was recorded on $B$. decumbens $\mathrm{CV}$. Basilisk followed by the control $P$. purpu- 
reum.

The two other Brachiaria Cultivars can also be recommended to the farmers according to their good yield.

\section{Acknowledgements}

We thank the Swedish International Development Cooperation Agency (SIDA) who funded this research via Bec'A-ILRI Hub. Special thanks are also addressed to Dr Sita Ghimire who chose INERA to implement this research in DRC. As a leader of the project, he monitored and evaluated all activities and revised the manuscript of this paper.

\section{Conflicts of Interest}

The authors declare no conflicts of interest.

\section{References}

[1] [FAO] Food Agriculture Organization (2013) Democratic Republic of the Congo BEFS Country Brief.

[2] [FAO] Food Agriculture Organization (2005) Livestock Sector Brief Democratic Republic of the Congo Livestock Sector Brief Food and Agriculture Organization of the United Nations FAO Livestock Information, Sector Analysis and Policy Branch AGAL.

[3] [SNSA] Service national des statistiques agricoles juillet 2012: Annuaire des statistiques agricoles (2000-2006) Ministère national de l'agriculture et du développement rural Secrétariat général à l'agriculture, pêche et élevage RDC.

[4] Katunga, M.M.D. (2014) Evaluation des légumineuses fourragères dans un système d'élevage Editions universitaires européennes (08-07-2014) ISBN: 976-613-1-58478-7. PhD Thesis, University of Lubumbashi, Lubumbashi, RDC.

[5] Liben, L. and Sperry, T. (1954) Soils and Vegetation Map of Belgian Congo, Rwanda and Burundi, 4 Nioka Explanation, Note of Soils and Vegetations Map of Ituri A,B,C. Publications of INEAC, Bruxelles, 31.

[6] SNSA Service national des statistiques agricoles RDC. Annuaire des statistiques agricoles (2011) Ministère national de l'agriculture et du développement rural Secrétariat général à l'agriculture, pêche et élevage RDC.

[7] Minagridral (2013) Ministère de l'agriculture et du développement rural, plan national d'investissement agricole PNIA 2013-2020 Ministère Agriculture et développement rural RDC.

[8] Ouma, E., Birachi, E., Pypers, P., Van Lauwe, B., Ekesa, B., Blomme, G., Chianu, J., Bouwmeester, H., Van Asten, P., Van Schagen, B., Nyagaya, M., Hakizimana, S., Bizimana, S., Gahigi, A., Ndayitegeye, O., Kantengwa, S., Lodi, L.J., Katunga, M.M., Bishikwabo, K. and Vigheri, N.P. (2011) CIALCA Baselines Report. 142 p. https://www.cialca.org/

[9] Njarui, D.M.G., Gatheru, M., Ghimire, S.R. and Mureithi, J.G. (2016) Effects of Seasons and Cutting Intervals on Productivity and Nutritive Value of Brachiaria Grass Cultivars in Semi-Arid Eastern Kenya. Climate Smart Brachiaria Grasses for Improving Livestock Production in East Africa-Kenya Experience Proceedings of the Workshop, Naivasha, Kenya, 14-15 September 2016, 46-61.

[10] Rodrigues, R.C., Sousa, T.V.R., Melo, M.A.A., Araújo, J.S., Lana, R.P., Costa, C.S., 
Oliveira, M.E., Parente, M.O.M. and Sampaio, I.B.M. (2014) Agronomic, Morphogenic and Structural Characteristics of Tropical Forage Grasses in Northeast Brazil. Tropical Grasslands-Forrajes Tropicales, 2, 214-222. https://doi.org/10.17138/TGFT(2)214-222

[11] Kifuko-Koech, M.N., Mutoko, M.C. and Ndung'U-Magiroi, K.W. (2016) Establishment and Early Growth of Brachiaria Grass Cultivars in Acidic Soils of Western Kenya. Climate Smart Brachiaria Grasses for Improving Livestock Production in East Africa-Kenya Experience Proceedings of the Workshop, Naivasha, Kenya, 14-15 September 2016, 80-89.

[12] Barahenda, M., Shem, M.N., Kanuya, N.L., Ntakabeza, I., Gasana, J., Uwimana, G., Umunezero, O. and Uwumukiza, D. (2007) Yield Potential Grass-Legume Pastures under Different Management Conditions. Research Journal of Animal Sciences, 1, 59-61.

[13] Ondiko, C.N., Njunie, M.N. and Ngode, L. (2016) Establishment and Growth of Brachiaria Grass Cultivars in the Coastal Lowlands of Kenya. Climate Smart Brachiaria Grasses for Improving Livestock Production in East Africa-Kenya Experience Proceedings of the Workshop, Naivasha, Kenya, 14-15 September 2016, 37-45. 